\title{
Estimation of green herbaceous phytomass from Landsat MSS data in Yellowstone National Park
}

\author{
EVELYN H. MERRILL, MARY K. BRAMBLE-BRODAHL, RONALD W. MARRS, \\ AND MARK S. BOYCE
}

Authors are assistant professor, Department of Zoology and Physiology, University of Wyoming, Laramie 82071-3166; research associate, Department of Zoology and Physiology, University of Wyoming, Laramie 82071. 3166; professor, Department of Geology, University of Wyoming, Laramie 82071-3006; and professor, Department of Zoology and Physiology, University of Wyoming, Laramie 82071-3166.

\begin{abstract}
Green herbaceous phytomass was measured in August 1987 in grassland and sagebrush-grassland communities of Yellowstone National Park and related to August 1987 Landsat MSS data. A linear model using MSS band 7 and the ratio of MSS bands 6 to 4 accounted for $63 \%$ of the variance in green herbaceous phytomass on ground-truth plots $(n=25)$. Error in estimates of green herbaceous phytomass was influenced by the relative amount of bare ground and the proportion of green to green plus dead herbaceous vegetation present at a site. The model was used to predict average green herbaceous phytomass in grassland and sagebrush-grassland communities across a $600 \mathrm{~km}^{2}$ portion of ungulate summer range in Yellowstone National Park for 11 years during 1972-1987 using additional Landsat MSS imagery. Green herbaceous phytomass declined seasonally from late July to early September. Annual deviations in green herbaceous phytomass from the 11-year average, corrected for date of satellite overpass, were not significantly related to precipitation or temperatures during the growing season but were related quadratically to December-March precipitation. Below-average green herbaceous phytomass in years of low and

Funding and data were provided by the National Park Service and the University of Wyoming-National Park Service Research Center under Contract UW-NPS \# 532754. Authors acknowledge the assistance of Don Despain, Francis Singer, and John Varley of Yellowstone National Park. Tammy Willette, Daryl Lutz, and Brad Sauer provided assistance in the field. Dave Sturges of the Rocky Mountain Forest and Range Experiment Station, Laramie, Wyo., provided the capacitance meter. Drs. Paul Tueller, Steven Buskirk, Nancy Stanton, and 2 anonymous reviewers provided helpful comments on the manuscript.
\end{abstract}

high winter precipitation may be related to the effects of snow accumulation and melt on phenological development (green wave) of plants across the summer range. Models based on MSS spectral data can provide useful descriptions of broadscale patterns of plant biomass in Yellowstone National Park but may not suffice when precise estimates are required. Climatic influences on plant phenology may confound the interpretation of results when spectral models are used to compare vegetation yield of forage availability among years.

Key Words: biomass, Landsat, multispectral scanner, Yellowstone National Park, ungulate summer range

Traditional methods for estimating forage availability to ungulates such as elk and bison are not practical for application over large geographic areas. Yet such estimates are necessary if we are to understand the dynamics between wide-ranging ungulate populations and their habitat (Strong et al. 1985). Spectral values recorded by the Landsat multispectral scanner (MSS) can be used to estimate vegetative characteristics, because foliage of plants differentially absorbs and reflects energy in the visible and near infrared regions of the spectra (Knipling 1970, Tucker and Sellers 1986, Tueller 1989).

Previous estimates of green phytomass made using spectral data have used near infrared and red wave bands in ratio (Colwell 1974, Pearson et al. 1976a, Boutton and Tieszen 1983) or linear combinations to form vegetation indices (Tucker et al. 1981, Richardson and Wiegand 1977, Weaver 1986). Richardson et al. (1983) found a 


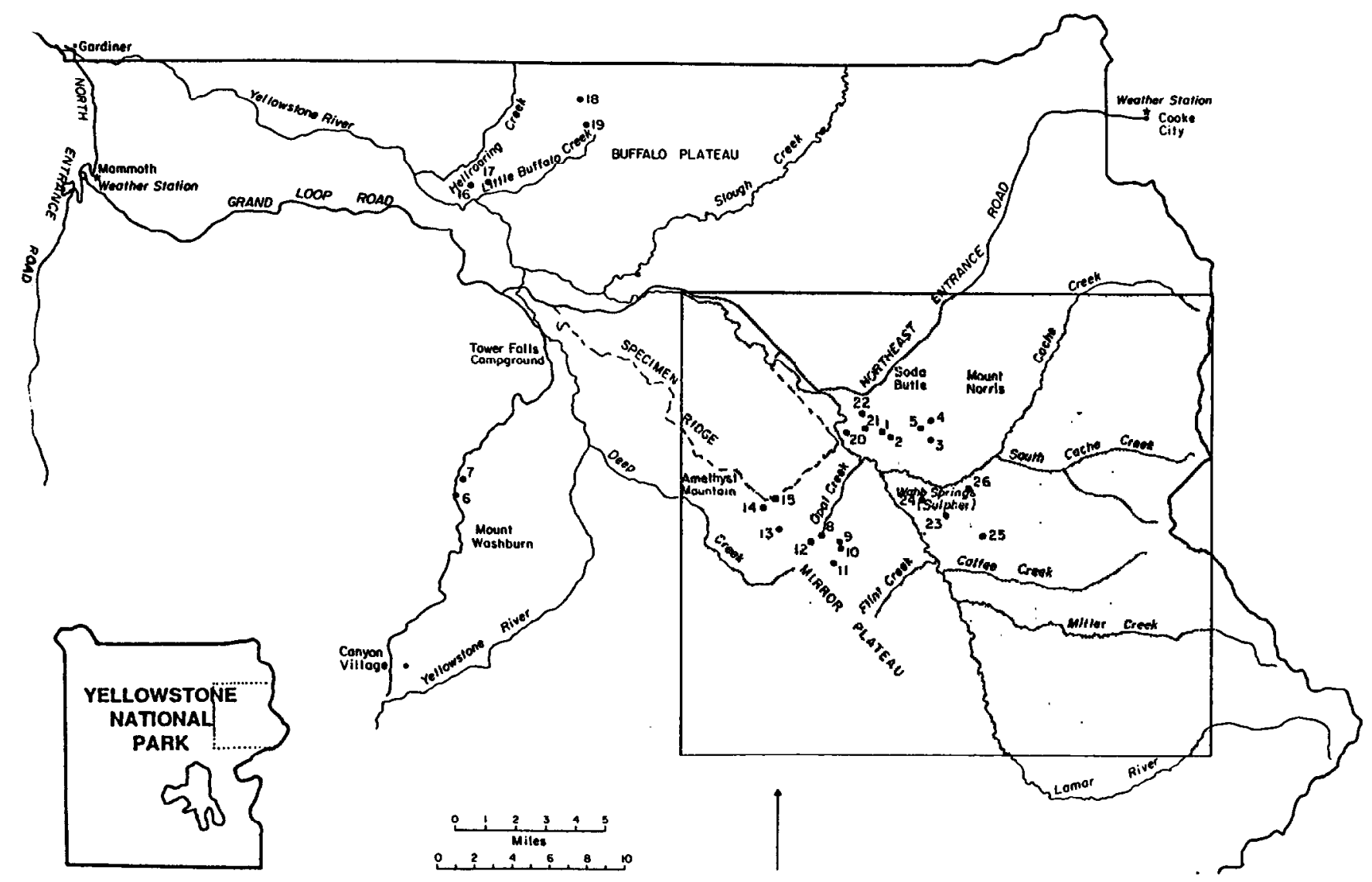

Fig. 1. Location of field plots in Yellowstone National Park sampled to determine relationships between green phytomass and reflectance values remotely sensed by Landsat multispectral scanner and the Cache/Calfee-Mirror Plateau study area (shaded) for which average green herbaceous phytomass was estimated during 1972-1987. See text for details.

nonlinear relationship between a perpendicular vegetation index (PVI) and biomass of Cynodon spp. in Texas. Kauth and Thomas (1976) combined 4 MSS bands to form the soil brightness index (SBI), which establishes the expected reflectance of soils, and the green vegetation index (GVI) which is orthogonal to the soil index.

Although Landsat multispectral information can provide useful indices to range vegetation, relationships for 1 site may not apply at other sites due to variation in range and soil conditions (Boyd 1986). Therefore, reliable estimates require that the procedures be tailored to site-specific conditions. The purpose of this paper is (1) to describe a spectral model designed to estimate green herbaceous phytomass in grassland and sagebrush communities of Yellowstone National Park using Landsat MSS spectral data, and (2) to evaluate the model for detecting annual trends in forage availability on ungulate summer range.

\section{Methods}

\section{Study Area}

The study was conducted in the northeast portion of Yellowstone National Park with major focus on the upper Lamar, Cache, and Calfee River drainages and the Mirror Plateau (Fig. 1). Geology of the park has been described by Keefer (1972) and topography, vegetation and soils have been described by Meagher (1973), and Houston (1982), Despain (1990). Climate data from Cook City, Montana (Fig. 1) were used to characterize weather patterns. Annual precipitation at Cooke City averaged $67.0 \mathrm{~cm}$ and daily temperature in January and July at Cooke City averaged $-10.3^{\circ} \mathrm{C}$ and $13.9^{\circ} \mathrm{C}$, respectively (U.S. Dep. Commerce 1970-1987).

Our work focused on the sagebrush and grassland portions of the study area at elevations of $2,000-2,780 \mathrm{~m}$. Sagebrush areas were dominated by big sagebrush (Artemisia tridentata Nutt.) communities with understories of bluebunch wheatgrass [Agropyron spicatum (Pursh) Scribn. \& Smith] in dry areas and Idaho fescue (Festuca idahoensis Elmer) in mesic areas. Silver sagebrush (Artemisia cana Pursh)/Idaho fescue communities were associated with stream banks and seeps. Idaho fescue/wheatgrass [Agropyron spicatum and A. caninum (L.) Beauv.] communities dominated at intermediate elevations. Grasslands occurred at high elevations and were dominated by Idaho fescue/tufted hairgrass [Deschampsia cespitosa (L.) Beauv.] and tufted hairgrass/sedge (Carex spp.). Elk (Cervus elaphus) and bison (Bison bison) are the most abundant ungulates in this area of the Park (Houston 1982).

\section{Model for Estimating Green Phytomass}

In 1987, we assessed regression models to estimate green phytomass from vegetation data collected 9-21 August 1987 at 25 ground-truth sites (Fig. 1) and Landsat imagery for 5 August 1987. Ground-truth sites comprised at least 2.7 ha (about 6 pixels of Landsat 5) of homogeneous vegetation. Phytomass was estimated using a double sampling approach (Wilm et al. 1944, Carande and Jameson 1986). At each ground-truth site, green herbaceous phytomass was estimated within fifty $0.18-\mathrm{m}^{2}$ microplots using either a capacitance meter (Neal et al. 1976), or, in remote areas into which the capacitance meter could not be transported easily, measurements of forb and grass volume (canopy coverage $X$ average plant height). Ten of the 50 microplots on each site were clipped to ground level and clippings were separated into standing dead herbaceous material, green forbs, and green graminoids. A criterion of $\geq 25 \%$ "green" was used to differentiate green from senesced 
plants. Current growth of shrubs, consisting of new growth of twigs and all green leaves, was estimated with a capacitance meter. Readings of the capacitance meter were taken before and after shrubs were removed from the microplots (Morris et al. 1976). Shrubs removed from the plot were clipped of current growth.

Clipped plant material was oven-dried at $100^{\circ} \mathrm{C}$ for 48 hours and weighed to the nearest $0.1 \mathrm{~g}$. An average dry to wet weight ratio of $0.70(n=50)$ was used to convert wet weight of standing dead herbaceous plants in each microplot to dry weight. Oven-dried weights of phytomass were regressed on capacitance or volume measurements and regressions were used to predict the dry weight of phytomass in the nonclipped microplots. Regressions of phytomass weights from capacitance meter readings explained more of the variation in green herbaceous phytomass (grasses plus forbs) $\left(r^{2}=0.73\right)$ than regressions of green forb $\left(r^{2}=0.45\right)$ and green grass $\left(r^{2}=0.63\right)$ phytomass based on plant volume. Regressions of current growth from the difference in capacitance readings before and after shrubs were removed from a microplot, explained $68 \%$ of the variance in shrub current growth.

Landsat data for 5 August 1987 were transferred from computer-compatible tape to the Map and Image Processing System (MIPS) for data processing and display. Ground-truth plots were mapped on ortho-photo quadrangle maps in the field and transferred to 1:58,000-scale color infrared aerial photographs in the lab. Plot locations on the photographs were digitized using a Panasonic video display camera which allowed the image processor to capture spectral information from the 3 spectral bands (red, green, IR). The computer image was aligned with the Landsat image to establish plot locations on the Landsat scene. Digital values of the 4 Landsat MSS bands were recorded for the plot location ( 2 pixels) and 4 adjacent pixels within the same vegetation community. The 6 values $(2.7 \mathrm{ha})$ for each band were averaged to repesent the spectral signature of the ground-truth plot.

Relationships between green phytomass at the 25 ground-truth sites and the MSS spectral values, linear combinations of the spectral values, and vegetation indices (Rouse et al. 1974, Kauth and Thomas 1976) for the sites were evaluated using least squares regression analysis (Kleinbaum and Kupper 1978). Three criteria were used to select the most appropriate regression model for estimating green phytomass from Landsat spectral data: a significant $\mathrm{F}$ value $(P \leq 0.05)$, an explanation of at least $50 \%$ of the variance in the phytomass data, and the lowest standard error of the estimate.

\section{Annual Estimates of Green Herbaceous Phytomass}

Annual estimates of average green herbaceous phytomass were derived for the grassland and sagebrush-grassland portions of a $600 \mathrm{~km}^{2}$ (Fig. 1) area of ungulate summer range during 1972-1986 using additional Landsat imagery for 10 years and the 1987 phytomass model. This procedure followed a 3-step process. First, Landsat data for previous years were calibrated to 1987 imagery conditions. Adjustments included corrections for machine differences in detector sensitivity and electronic gain among Landsat satellites (Markham and Barker 1987) and for environmental differences, such as sun angle and haze. Corrections for environmental differences were made by selecting 4 reference areas that had little to no vegetation (e.g., bare rock, lakes, and travertine deposits near a hot spring) and regressing spectral values in 1987 against the values for the same areas in other years (Merrill et al. 1988).

The second step involved the elimination of forests and clouds so that average estimates of green herbaceous phytomass for the study area represented only grassland and sagebrush-grassland areas. A principal component analysis (PCA), using spectral values for all 4 MSS bands, was performed on a "training area" within the study area to distinguish between forested and nonforested pixels. An appropriate threshold value, below which areas were classified as forests, was determined by visually comparing the display of the PCA index to forested areas on Yellowstone Park cover maps. The PCA index was then calculated for each pixel within the $600 \mathrm{~km}^{2}$ area. All pixels with a PCA value below

Table 1. Green phytomass (kg/ha), standing dead herbaceous phytomass (kg/ha), current growth of shrubs (CG), and bare ground (\% cover) at 25 sites sampled in Yellowstone National Park on 9-21 August 1987.

\begin{tabular}{|c|c|c|c|c|c|c|c|}
\hline $\begin{array}{l}\text { Plot } \\
\text { Number }\end{array}$ & $\begin{array}{l}\text { Total' } \\
\text { Green }\end{array}$ & $\begin{array}{c}\text { Green }^{2} \\
\text { Herbaceous }\end{array}$ & $\begin{array}{c}\text { Shrub } \\
\text { CG }\end{array}$ & $\begin{array}{l}\text { Green } \\
\text { Forb }\end{array}$ & $\begin{array}{l}\text { Green } \\
\text { Grass }\end{array}$ & $\begin{array}{l}\text { Standing } \\
\text { Dead }\end{array}$ & $\begin{array}{l}\text { Bare ground } \\
\text { Cover }\end{array}$ \\
\hline & $-\cdots$ & . & $\ldots$ & 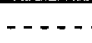 & $\ldots$ & $\ldots$ & $. \%-$ \\
\hline 1 & 616.7 & 580.2 & 36.5 & 167.1 & 413.1 & 40.8 & 22.2 \\
\hline 2 & 1978.7 & 1193.6 & 785.1 & 366.1 & 827.5 & 104.2 & 10.6 \\
\hline 3 & 3153.9 & 3153.9 & 0.0 & 297.8 & 2856.2 & 165.7 & 3.3 \\
\hline 4 & 885.0 & 638.7 & 246.3 & 183.7 & 455.0 & 59.0 & 34.4 \\
\hline 5 & 960.2 & 960.2 & 0.0 & 267.6 & 692.6 & 121.4 & 31.7 \\
\hline 6 & 673.4 & 638.1 & 35.3 & 203.5 & 434.6 & 39.0 & 2.6 \\
\hline 7 & 1032.2 & 1032.2 & 0.0 & 138.9 & 893.3 & 79.9 & 2.1 \\
\hline 8 & 1077.4 & 1077.4 & 0.0 & 269.6 & 807.8 & 380.2 & 3.9 \\
\hline 9 & 694.8 & 694.8 & 0.0 & 178.5 & 516.3 & 101.6 & 7.1 \\
\hline 10 & 1087.3 & 1087.3 & 0.0 & 323.7 & 763.6 & 226.2 & 6.0 \\
\hline 11 & 838.6 & 838.6 & 0.0 & 276.6 & 561.7 & 123.2 & 12.0 \\
\hline 12 & 1521.5 & 1521.5 & 0.0 & 182.8 & 1338.7 & 555.3 & 6.0 \\
\hline 13 & 1536.8 & 1536.8 & 0.0 & 371.0 & 1165.9 & 369.9 & 2.4 \\
\hline 14 & 1020.3 & 1020.3 & 0.0 & 249.8 & 770.5 & 302.8 & 2.9 \\
\hline 15 & 1627.9 & 1627.9 & 0.0 & 481.5 & 1146.0 & 289.0 & 6.3 \\
\hline 16 & 576.8 & 530.8 & 46.2 & 60.8 & 469.9 & 107.4 & 46.5 \\
\hline 17 & 1180.8 & 964.7 & 216.1 & 224.4 & 740.3 & 208.9 & 11.9 \\
\hline 18 & 907.5 & 907.5 & 0.0 & 714.0 & 193.2 & 371.8 & 47.7 \\
\hline 19 & 946.0 & 946.0 & 0.0 & 260.9 & 685.1 & 232.4 & 3.0 \\
\hline 20 & 481.9 & 363.5 & 118.4 & 80.2 & 283.3 & 130.6 & 6.4 \\
\hline 21 & 1030.5 & 963.4 & 67.2 & 143.3 & 820.1 & 294.1 & 1.6 \\
\hline 23 & 684.9 & 684.9 & 0.0 & 212.2 & 472.7 & 510.6 & 6.2 \\
\hline 24 & 526.5 & 526.5 & 0.0 & 202.3 & 324.2 & 474.7 & 2.6 \\
\hline 25 & 778.5 & 778.5 & 0.0 & 236.8 & 541.7 & 316.7 & 4.5 \\
\hline
\end{tabular}

'Total Green = green herbaceous phytomass plus current shrub growth (new twigs and all green leaves).

${ }^{2}$ Green Herbaceous = green grass plus green forb phytomass. 
the threshold were omitted from our estimate of average green herbaceous phytomass. Similarly, pixels with a PCA value above a designated threshold were covered by clouds and were omitted from the estimate of average green herbaceous phytomass.

Finally, calibrated spectral values were used in the model to obtain a pixel-by-pixel estimate of green herbaceous phytomass in the sagebrush-grassland and grassland portions of the study area for the 11 years for which we had Landsat imagery. Pixel values were then averaged across the study area to obtain an annual estimate of average green herbaceous phytomass for the same grassland and sagebrush-grassland portions of the study area.

\section{Results}

\section{Phytomass at Ground-truth Sites}

Estimates of total green phytomass (herbaceous phytomass plus current growth of shrubs) on the $\mathbf{2 5}$ ground-truth sites sampled in 1987 ranged from 482 to $3,154 \mathrm{~kg} /$ ha (Table 1). At sites dominated by sagebrush, new twigs and leaves of shrubs averaged $28 \%$ of the total green phytomass. In grassland communities, grass comprised over $70 \%$ of green herbaceous phytomass, on average. Highest green herbaceous phytomass occurred on site 3, which was dominated by timothy (Phleum pratense L.). Forbs predominated only on the Buffalo Plateau where they comprised $79 \%$ of green herbaceous phytomass on 1 site. Percentage of senesced material in the standing crop averaged $20 \%(5-48 \%)$ of total phytomass (Table 1).

\section{Green Phytomass Model}

Correlations between spectral bands, band ratios, or vegetation indices and green phytomass were generally weak (Table 2). Among the linear models we tested, no combination of MSS spectral bands or band ratios explained more than $50 \%$ of the variation in total green phytomass, current growth of shrubs, or green forb phytomass, while several indices explained $50 \%$ of the variation in green grass and green herbaceous (grass plus forb) phytomass. The equation which best met our criteria for model selection was:

$$
\text { GHP = } 2687 \text { (MSS6/MSS4) - 87.68 MSS7 - } 396.79
$$

where GHP is green herbaceous phytomass (grass plus forbs), $r^{2}=$ $0.63, P<0.001$, S.E. $=350.5 \mathrm{~kg} /$ ha. Logarithmic transformations of our data did not account for more than an additional $1 \%$ of the variation in any of the models and were avoided due to additional
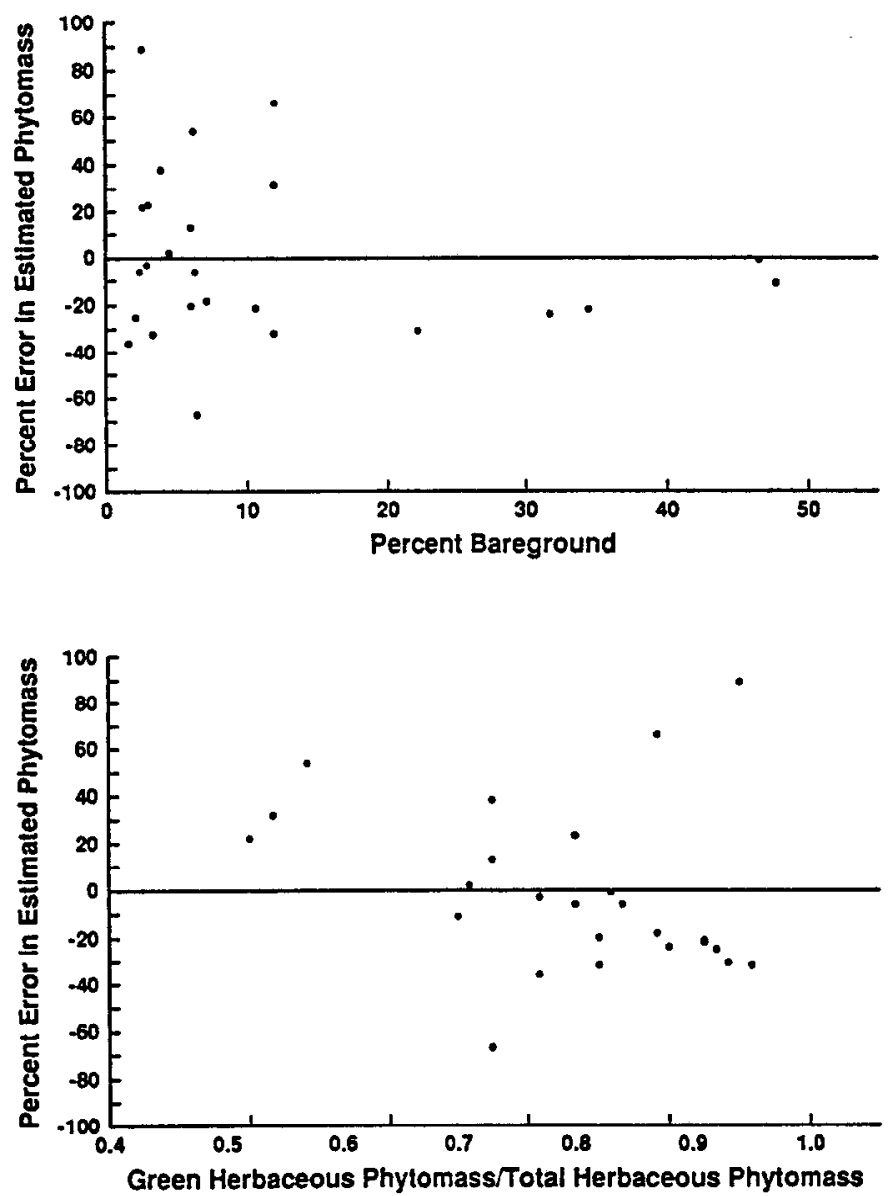

Fig. 2. Effects of bare ground (a) and plant senescence (b) on the percent of error in estimating green herbaceous phytomass of field plots in August 1987 using Eq. 1.

complexity of those transformations in our image processing system.

Potential sources of error in our model are illustrated in Fig. 2. Green herbaceous phytomass predicted by equation 1 is frequently overestimated when the ratio of green herbaceous phytomass to

Table 2. Linear correlation coefficients ( $(r)$ between selected vegetation measurements and Landsat MSS bands values, band ratios, and vegetation indices $(\mathrm{n}=\mathbf{2 5}$ ). NS indicates $P \geq \mathbf{0 . 0 5}$.

\begin{tabular}{|c|c|c|c|c|c|}
\hline Parameter & Total green & Green herbaceous & Green forb & $\begin{array}{c}\text { Shrub } \\
\text { CG }\end{array}$ & $\begin{array}{c}\% \text { Cover }^{1} \\
\text { bare ground }\end{array}$ \\
\hline $\begin{array}{l}\text { MSS Band } 4 \\
\text { MSS Band } 5 \\
\text { MSS Band } 6 \\
\text { MSS Band } 7\end{array}$ & $\begin{array}{c}-0.55 \\
\text { NS } \\
\text { NS } \\
\text { NS }\end{array}$ & $\begin{array}{c}-0.64 \\
-0.46 \\
0.42 \\
\text { NS }\end{array}$ & $\begin{array}{r}\text { NS } \\
\text { NS } \\
0.53 \\
0.51\end{array}$ & $\begin{array}{c}\text { NS } \\
\text { NS } \\
-0.42 \\
-0.45\end{array}$ & $\begin{array}{l}\text { NS } \\
\text { NS } \\
\text { NS } \\
\text { NS }\end{array}$ \\
\hline $\begin{array}{lr}\text { RATIO MSS6/MSS4 } \\
& \text { MSS6/MSS5 } \\
& \text { MSS7/MSS4 } \\
\text { VI }^{2} & \\
\text { TVI }^{3} & \\
\text { GVI }^{4} & \\
\text { PVI }^{3} & \end{array}$ & $\begin{array}{l}0.42 \\
0.42 \\
\text { NS } \\
\text { NS } \\
\text { NS } \\
\text { NS } \\
\text { NS }\end{array}$ & $\begin{array}{l}0.57 \\
0.56 \\
0.52 \\
0.51 \\
0.51 \\
\text { NS } \\
0.31\end{array}$ & $\begin{array}{r}0.50 \\
0.44 \\
0.49 \\
0.44 \\
0.44 \\
\text { NS } \\
\text { NS }\end{array}$ & $\begin{array}{l}-0.42 \\
-0.40 \\
-0.45 \\
-0.43 \\
-0.43 \\
\text { NS } \\
\text { NS }\end{array}$ & $\begin{array}{l}\text { NS } \\
\text { NS } \\
\text { NS } \\
\text { NS } \\
\text { NS } \\
\text { NS } \\
\text { NS }\end{array}$ \\
\hline
\end{tabular}

Correlations are based on arcsine-square root transformations of percentage values

2Vegetation index: VI = (MSS7-MSS5)/(MSS7+MSS5), Rouse et al. 1974.

3ransformed vegetation index: TVI=SQRT(VI+0.05), Rouse ct al. 1974.

${ }^{4}$ Green vegetation index: GVI $=-0.42305$ (MSS4) - 0.5054 (MSS5)

sPerpendicular index: PVI $=1.08$ (MSS7) $/ 1.03$ (MSS5-6) 
Table 3. Year and date of Landsat satellite overpass, Landsat satellite, total number of pixels within the Cache/Calfee-Mirror Plateau study area, total number non-forested pixels for which average green herbaceous phytomass (GHP) was estimated, number of pixels covered by clouds, and annual estimates of average green herbaceous phytomass $(\mathrm{kg} / \mathrm{ha})$.

\begin{tabular}{|c|c|c|c|c|c|c|c|c|c|}
\hline \multirow[t]{2}{*}{ Year } & \multirow{2}{*}{$\begin{array}{c}\text { Date of } \\
\text { Over }\end{array}$} & \multirow{2}{*}{$\begin{array}{l}\text { Landsat } \\
\text { satellite }\end{array}$} & \multicolumn{2}{|c|}{ Total Area } & \multicolumn{2}{|c|}{ Grasslands } & \multicolumn{2}{|c|}{ Cloud Cover } & \multirow{2}{*}{ GHP } \\
\hline & & & Pixels' & Area & Pixels & Area & Pixels & & \\
\hline & & & (no) & $\left(\mathrm{km}^{2}\right)$ & (no) & $\left(\mathbf{k m}^{2}\right)$ & (no) & $(\%)$ & $(\mathrm{kg} / \mathrm{ha})$ \\
\hline 1972 & $8 / 07$ & 1 & 148992 & 671 & 57375 & 258 & 0 & 0 & 1409 \\
\hline 1973 & $8 / 20$ & 1 & 148772 & 670 & 46671 & 210 & 4867 & 10 & 722 \\
\hline 1974 & $9 / 02$ & 1 & 148480 & 669 & 42286 & 190 & 0 & 0 & 633 \\
\hline 1975 & $8 / 10$ & 1 & 146432 & 659 & 46949 & 211 & 0 & 0 & 1707 \\
\hline 1976 & $9 / 09$ & 1 & 147456 & 664 & 52902 & 238 & 0 & 0 & 913 \\
\hline 1978 & $7 / 25$ & 3 & 145290 & 654 & 49173 & 221 & 0 & 0 & 1050 \\
\hline 1979 & $7 / 29$ & 2 & 204800 & 665 & 68632 & 223 & 1917 & 3 & 1806 \\
\hline 1981 & $8 / 23$ & 2 & 204800 & 665 & 58361 & 190 & 0 & 0 & 915 \\
\hline 1984 & $8 / 12$ & 5 & 204800 & 665 & 70246 & 228 & 13813 & 20 & 964 \\
\hline 1986 & $8 / 02$ & 5 & 204800 & 665 & 68726 & 223 & 1834 & 3 & 1592 \\
\hline 1987 & $8 / 05$ & 5 & 204800 & 665 & 60529 & 197 & 3072 & 5 & 1204 \\
\hline
\end{tabular}

'Geometrically uncorrected pixel size $(57 \times 79 \mathrm{~m}): 1972-1978$

Geometrically corrected pixel size $(57 \times 57 \mathrm{~m}): 1979-1987$

total standing herbaceous phytomass (green plus dead) is low and tends to be underestimated when bare ground is high.

\section{Annual Estimates of Green Herbaceous Phytomass}

Average green herbaceous phytomass in the grassland and sagebrush-grassland portions of the study area ranged from 633 $\mathrm{kg} / \mathrm{ha}$ in 1974 to $1,806 \mathrm{~kg} / \mathrm{ha}$ in 1979 (Table 3). A seasonal decline in green herbaceous phytomass was observed in relation to date of satellite overpass (Fig. 3). The following maxima function curve (Spain 1982) was fit to the 11 annual estimates:

$$
\text { GHP }=A \times \exp (n x)
$$

where GHP = green herbaceous phytomass $(\mathrm{kg} / \mathrm{ha})-600, \mathrm{x}=$ julian date of sampling - 100, A = 17,206, $\mathrm{n}=0.068,\left(r^{2}=0.61, P<0.05, \mathrm{n}=\right.$ 11). The equation represents the average seasonal decline in green herbaceous phytomass from the end of July to the beginning of September for the 11-year period of the study (Fig. 3). Deviations

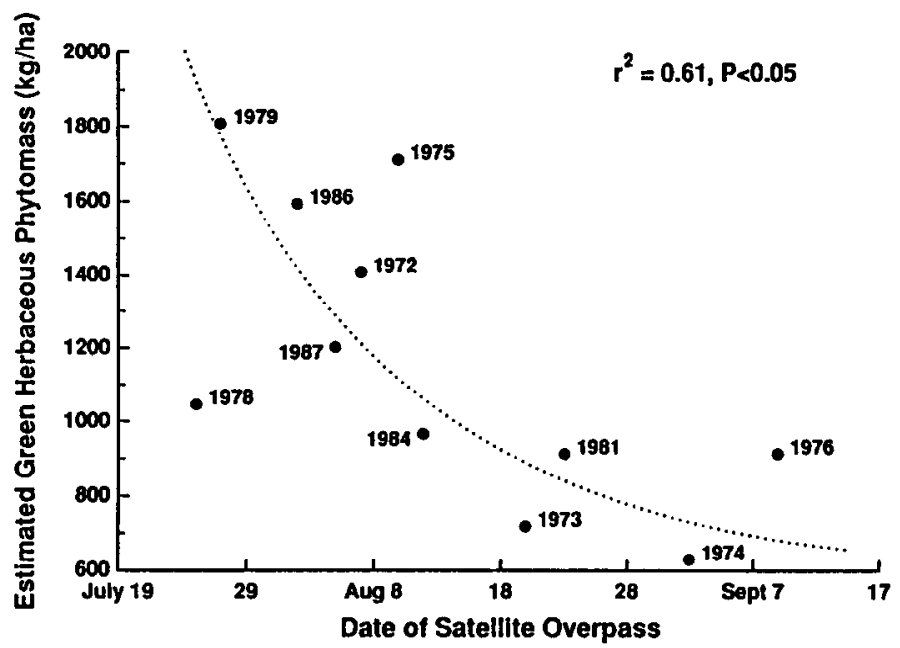

Fig. 3. Average green herbaceous phytomass (GHP) (kg/ha), estimated from Landsat MSS spectral data, for the grassland and sagebrushgrassland portions of the Cache/Calfree-Mirror Plateau study area during 11 years from 1972-1987. The dotted line represents the average seasonal decline in green herbaceous phytomass for the years of the study.

in our annual estimates of green herbaceous phytomass from this average were quadratically related to December-March precipitation ( $r^{2}=0.81, P<0.01$, Fig. 4). No significant relationship was found between deviations in annual estimates of green herbaceous

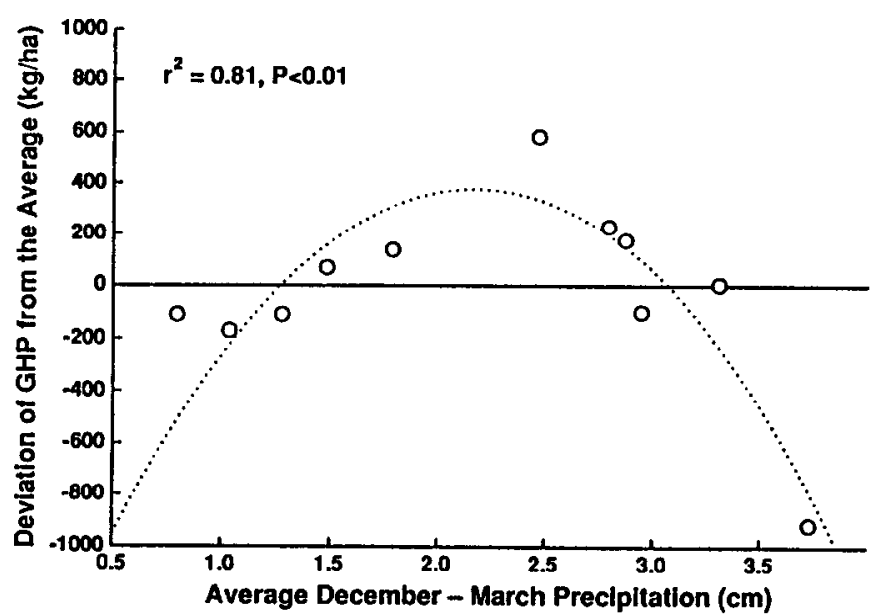

Fig. 4. The deviation in green herbaceous phytomass (GHP) (kg/ha) from the average seasonal decline in green herbaceous phytomass in relation to average December-March precipitation (cm).

phytomass from the average and temperature or total precipitation during the growing season.

\section{Discussion}

Our estimates of green herbaceous phytomass in northeastern Yellowstone National Park are well within values reported for the habitat types we sampled (Mueggler and Steward 1980) suggesting that canopy spectro-reflectance in grassland and sagebrushgrasslands of Yellowstone National Park can be a useful estimator of green herbaceous phytomass. Although the precision of our model is comparable to those for other grassland communities (Boutton and Tieszen 1983, Weaver 1986), errors can be large and would limit the use of this technique in investigations requiring precise estimates. Boutton and Tieszen (1983) found that average percent error of the estimate increased as the proportion of live biomass of the standing biomass declined. Pearson et al. (1976b) found estimates of green phytomass from spectral models were unreliable when live or green vegetation comprised less than $30 \%$ of the total phytomass (green plus standing dead). We had no plots in 1987 on which green herbaceous phytomass was less than $50 \%$ of the total herbaceous vegetation (green plus standing dead) but found that green herbaceous phytomass was overestimated when the proportion of green to total (green plus standing dead) phytomass in a plot was less than $60 \%$. Green herbaceous phytomass was 
underestimated in plots with greater than $20 \%$ bare ground. Soil background signals can have an overriding effect on predicting vegetative conditions (Huete et al. 1984, Elvidge and Lyon 1985). We did not collect data on the spectral characteristics of soils at our ground-truth sites and in the future it may be possible to improve these estimates with corrections for soil reflectances.

Estimates of green herbaceous phytomass indicated a rapid seasonal decline in green herbaceous phytomass from late July to early September in the Cache-Calfee/Mirror Plateau area (Fig. 3). Most studies have reported positive, linear relationships between winter-spring precipitation and herbaceous yield in grassland and sagebrush-grassland communities (Craddock and Forsling 1938, Blaisdell 1958, Whysong 1973). In this study, we found that green herbaceous phytomass in late summer was below the seasonal average when December-March precipitation was low or high (Fig. 4). Because spectral models like ours predict green, rather than total phytomass, we suggest that average green herbaceous phytomass was influenced by annual variation in phenology (green wave) which is determined by winter snow accumulation and timing of snowmelt. When winter snow accumulations were low, snowmelt and spring green-up occurred early and plants cured early so that less green herbaceous phytomass was available in late summer than in years of average snow accumulation. Likewise, in years of heavy snowfall, the amount of green herbaceous phytomass measured in late summer was below average because snow melt occurred late, delaying phenological development. The quadratic relationship between variation in green herbaceous phytomass and winter precipitation we present is highly dependent on a few data points and it needs to be substantiated further. Yet, because we found no significant relationships between green herbaceous phytomass and precipitation or temperatures during the growing season, we hypothesize that the pattern of snow accumulation and melt is the dominant factor influencing phenological development in these high elevation grasslands. This hypothesis is consistent with the results of Frank (1990), who found that concentration of green biomass $\left(\mathrm{mg} \mathrm{cc}^{-1}\right)$ at his field sites on the CacheCalfee summer ranges was significantly related to days after snowmelt. Timing of snowmelt has been shown to influence phenology of plants in other high elevation grasslands of this region (Canaday and Fonda 1974, Weaver 1974).

Snow accumulation and melt also may influence total yield, but this relationship does not seem to be a simple one. For example, in Montana, Weaver and Collins (1977) found a decline in herbaceous yield of Festuca idahoensis/Agropyron caninum vegetation under snowbanks relative to driftless areas. They attributed reduced yield under the snowbank to a shortened growing season caused by late snowmelt, but similar ending dates to the growing season. Knight et al. (1979), however, found that prolonged snowcover, due to artificial augmentation of snow in subalpine grasslands in southeast Wyoming, decreased yield in wet meadows but increased yield in dry meadows. They suggested that additional water in dry meadows may have wet the soil to a greater depth than normal, thereby providing a greater supply of water for plant growth via deeper plants roots or capillary movement from below.

In addition to climatic factors, Frank (1990) found that ungulates in this area can stimulate aboveground plant growth. During the period of our study, ungulate numbers increased to record highs (Singer et al. 1989). However, we did not find a correlation between ungulate population numbers and the deviation in green herbaceous phytomass from the mean in the years of the study, implying that ungulates were not affecting green herbaceous phytomass.

We conclude that Landsat MSS data can provide estimates of green herbaceous phytomass in Yellowstone National Park that are useful for landscape questions (e.g., Merrill and Boyce 1991) but may not be precise enough for other purposes. It is possible that Landsat thematic mapper data may improve the precision of the phytomass estimates because more band options are available for model development. Nonetheless, annual variation in phenology may confound the interpretation of results when spectral models are used to examine trends in vegetation production or forage availability across years.

\section{Literature Cited}

Blaisdell, J.P. 1958. Seasonal development and yield of native plants on the Upper Snake River Plains and their relation to certain climatic factors. USDA Tech. Bull. 1190. Washington, D.C.

Boutton, T.W., and L.T. Tieszen. 1983. Estimation of plant biomass by spectral reflectance in an East African grassland. J. Range Manage. 36:213-216.

Boyd, W.E. 1986. Correlation of rangeland brush canopy cover with Landsat MSS data. J. Range Manage. 39:268-271.

Canaday, B.B., and R.W. Fonda. 1974. The influence of subalpine snowbanks on vegetation pattern, production and phenology. Bull. Torrey Bot. Club. 101:340-350.

Carande, V., and D.A. Jameson. 1986. Combination of weight estimates with clipped sample data. J. Range Manage. 39:88-89.

Colwell, J.E. 1974. Vegetation canopy reflectance. Remote Sens. of Environ. 3:175-183.

Cranddock, G.W., and C.L. Forsling. 1938. The influence of climate and grazing on spring-fall sheep range in southern Idaho. USDA Tech. Bull. 600. Washington, D.C.

Despain, D.G. 1990. Yellowstone vegetation: consequences of environment and history in a natural setting. Roberts Rinehart Publ. Boulder.

Elvidge, C.D., and R.J.P. Lyon. 1985. Influence of rock-soil spectral variation on the assessment of green biomass. Remote Sens. of Environ. 17:265-279.

Frank, D.A. 1990. Interactive ecology of plants, large mammalian herbivores and drought in Yellowstone National Park. Ph.D. thesis. Syracuse Univ., Syracuse.

Houston, D.B. 1982. The Northern Yellowstone elk. Macmillan Publ. Co., N.Y.

Huete, A.R., D.F. Post, and R.D. Jackson. 1984. Soil spectral effect on 4-space vegetation discrimination. Remote Sens. of Environ. 15:155-165.

Kauth, R.J., and G.S. Thomas. 1976. The tasselled cap: a graphic description of the spectral-temporal development of agricultural crops as seen by Landsat. Proc. Machine Processing of Remotely Sensed Data. IEEE Cat. 76 CH 1103-1 MPRSD. LARS. p. 4b-41-51.

Kleinbaum, D.G., and L.L. Kupper. 1978. Applied regression analysis and other multivariable methods. Duxbury Press, North Scituate, Mass.

Keefer, W.R. 1972. Geologic story of Yellowstone National Park. Geological Survey Bull. 1347. Gov. Print. Off., Washington, D.C.

Knight, D.H., S.W. Weaver, C.R. Starr, and W.H. Romme. 1979. Differential response of subalpine meadow vegetation to snow augmentation. J. Range Manage. 32:356-359.

Knipling, E.B. 1970. Physical and physiological asis for the reflectance of visible and near-infrared radiation from vegetation. Remote Sens. of Environ. 1:155-159.

Markham, B.L., and J.L. Barker. 1987. Radiometric properties of U.S. processed landsat MSS data. Remote Sens. of Environ. 22:39-71.

Meagher, M.M. 1973. The bison of Yellowstone National Park. National Park Service, Sci. Monogr. Series 1.

Merrill, E.H., M.S. Boyce, R.W. Marrs, and M.K. Bramble-Brodahl. 1988. Grassland phytomass, climatic variation and ungulate population dynamics in Yellowstone National Park. Final Rep., Yellowstone National Park. 63 pp.

Merrill, E.H., and M.S. Boyce. 1991. Summer range and elk population dynamics in Yellowstone National Park. pp. 263-273 In: Robert B. Keiter and Mark S. Boyce (eds). The Greater Yellowstone Ecosystem: Redefining America's wilderness heritage. Yale Univ. Press, New Haven.

Morris, M.J., K.L. Johnson, and D.L. Neal. 1976. Sampling shrub ranges with an electronic capacitance instrument. J. Range Manage. 29:78-81.

Mueggler, W.R., and W.L. Stewart. 1980. Grassland and shrubland habitat types of western Montana. USDA Forest Serv., Gen. Tech. Rep. Int-66.

Neal, D.L., P.O. Currie, and M.J. Morris. 1976. Sampling herbaceous native vegetation with an electronic capacitance instrument. I. Range Manage. 29:74-77. 
Pearson, R.L., C.J. Tucker, and L.D. Miller. 1976a. Spectral mapping of shortgrass prairie biomass. Photogramm. Eng. Remote Sens. 42:317-323.

Pearson, R.L., L.. Miller, and C.J. Tucker, 1976b. Hand-held spectral radiometer to estimate gramineous biomass. Appl. Optics 15:418-418.

Richardson, A.J., and C.L. Wiegand. 1977. Distinguishing vegetation from soil background information. Photogramm. Eng. Remote Sens. 43:15411552.

Richardson, A.J., J.H. Everitt, and H.W. Gausman. 1983. Radiometric estimation of biomass and nitrogen content of Alicia grass. Remote Sens. of Environ. 13:179-184.

Singer, F.J., W. Schreier, J. Oppenheim, and E.O. Garton. 1989. Drought, fires, and large mammals. BioSci. 39:716-722.

Spain, J.D. 1982. Basic microcomputer models in biology. AddisonWesley Publ., Reading.

Strong, L.L., R.W. Dana, and L.H. Carpenter. 1985. Estimating phytomass of sagebrush habitat types from microdensitometer data. Photogramm. Eng. Remote Sens. 51:469-474.

Tucker, C.J., B.N. Holden, J.H. Elgin, and J.E. McMurthey. 1981. Remote sensing of total dry matter accumulation in winter wheat. Remote Sens. of Environ. 11:171-188.

Tucker, C.J., and P.J. Sellers. 1986. Satellite remote sensing of primary production. Int. J. Remote Sens. 7:1395-1416.
Tueller, P.T. 1989. Remote sensing technology for rangeland management applications. J. Range Manage. 42:442-453.

U.S. Dep. Commerce and National Oceanic Atmospheric Administration. 1970-1988. Climatological data. Wyoming, Montana. Annual summaries. U.S. Gov. Print. Off., Washington, D.C.

Weaver, T. 1974. Ecological effects of weather modification: effect of late snowmelt on Festuca idahoensis Elmer meadows. Amer. Midl. Natur. 92:346-356.

Weaver, T., and D. Collins. 1977. Possible effects of weather modification (increased snowpack) on Festuca idahoensis meadows. J. Range 30:451455.

Weaver, J.W. 1986. Range site reflectance characteristics measured by Landsat MSS and color infrared low aerial photography in South Dakota mixed prairie. Ph.D. Thesis. Univ. Wyoming, Laramie.

Whysong, G.L. 1973. Development and evaluation of statistical models for predicting perennial grass production in north central Wyoming. Ph.D. Thesis. Univ. Wyoming, Laramie.

Wilm, H.J., D.F. Costello, and G.E. Klipple. 1944. Estimating forage yield by the double-sampling method. Amer. Soc. Agron. J. 36:194-203. 